\title{
Coral-Red Fluorescence of Erythrasma Plaque
}

"Gonzalo Blasco-Morente, ${ }^{1}$ Salvador Arias-Santiago, ${ }^{2}$ Israel Pérez-López, ${ }^{2}$ Antonio Martínez-López²

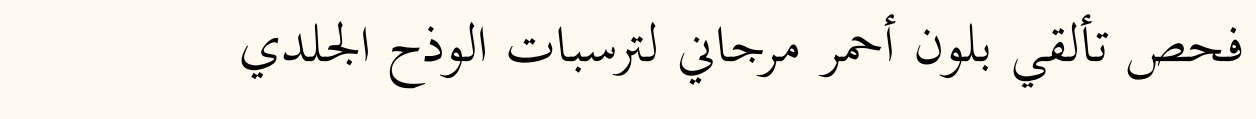

غونزالو بلاسكو-مورينتى، سلفادور أرياس-سانتياغو، إسرائيل بيريز-لوبيز، أنطونيو مارتينيز-لوبيز
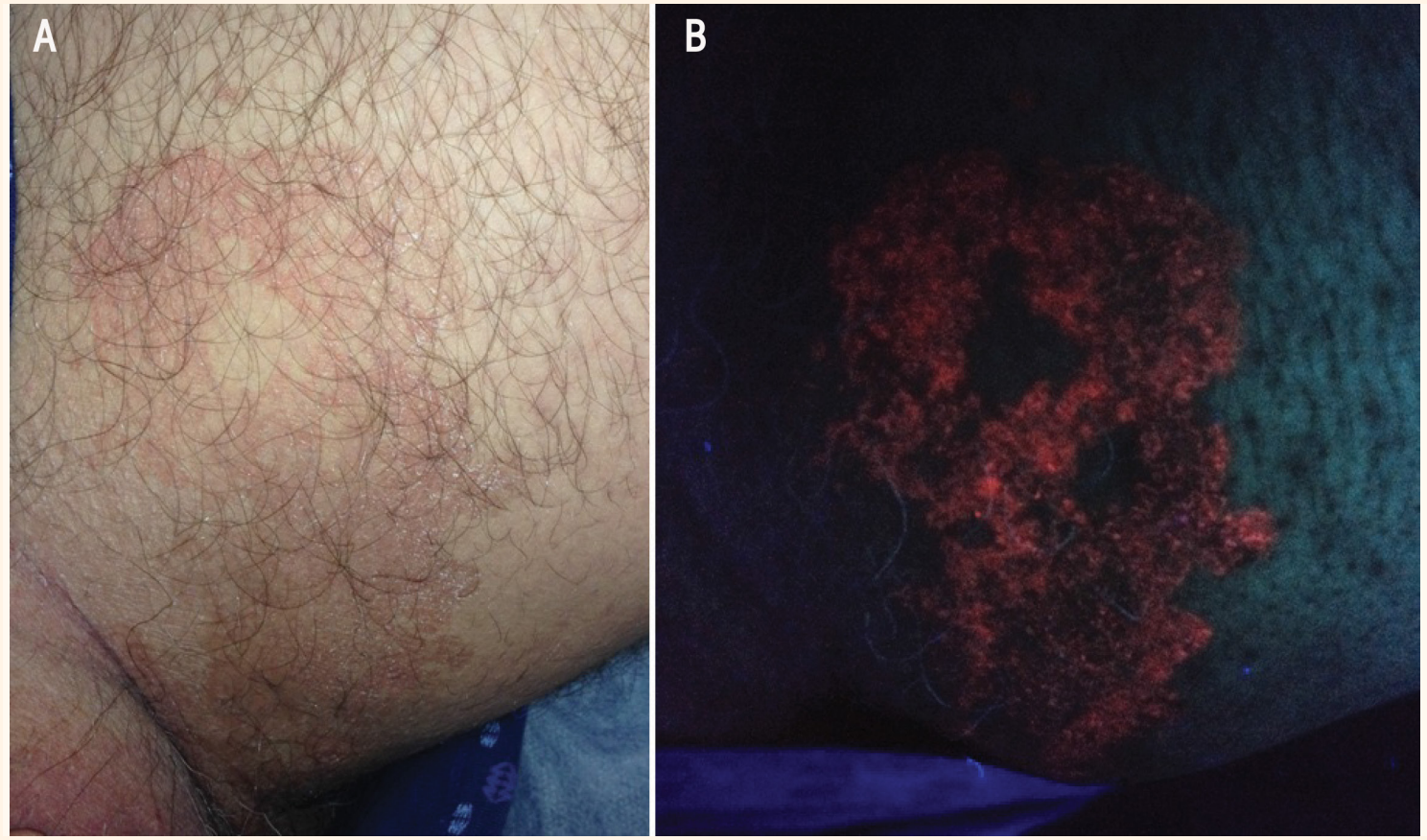

Figure 1A \& B: A: Diffuse, brownish, well-defined, scaly plaque in the left inguinal region of a 50-year-old man. Note the 'cigarette paper' appearance. B: Wood's light skin examination of the plaque showing bright coral-red fluorescence characteristic of erythrasma.

A 5O-YEAR-OLD MAN PRESENTED TO THE Department of Dermatology, University Hospital Complex of Granada, Granada, Spain, in 2015 with a slightly pruritic rash on the left groin, which he had had for two years. He had attended the hospital previously and been diagnosed with eczema and tinea cruris. This had been treated with topical steroids and antifungal drugs (methylprednisolone and sertaconazole) for several months without improvement. A physical examination of the patient showed a diffuse, brownish, well-defined, scaly plaque in the left inguinal region [Figure 1A]. A potassium hydroxide preparation of tissue scrapings was negative for fungal elements or cultures. The coralred fluorescence of the plaque under a Wood's lamp
(WL) examination was characteristic of erythrasma [Figure 1B]. The patient was treated with $500 \mathrm{mg}$ of oral erythromycin every 12 hours for 14 days, with progressive healing observed over three weeks.

\section{Comment}

Erythrasma is a localised and chronic skin infection caused by Corynebacterium minutissimum. ${ }^{1-3}$ It appears as patches that are either asymptomatic and well-defined or irregular in shape and size and red/ brown in colour. ${ }^{3-5}$ The diagnosis is usually clinical, but a WL examination can show characteristic fluorescence due to coproporphyrin III produced by the bacteria. ${ }^{2,3}$ The WL emits ultraviolet A radiation with 
wavelengths between $320-400 \mathrm{~nm}$ and is useful in the diagnosis of disorders of pigmentation, skin infections (such as erythrasma) and porphyrias. ${ }^{2}$ However, microscopic examinations (e.g. Gram staining of an epidermis scraping to reveal Gram-positive filaments and rods) and cultures on different types of media (e.g. $20 \%$ fetal bovine serum, $2 \%$ agar and $78 \%$ tissue culture medium \#199) may be required in certain cases. ${ }^{4,5} \mathrm{~A}$ potassium hydroxide preparation of tissue scrapings can rule out concomitant infections, especially in patients with interdigital involvement. ${ }^{4}$ The differential diagnosis of erythrasma includes candidiasis, psoriasis and dermatophytosis. ${ }^{1-5}$ The most effective treatment is $500 \mathrm{mg}$ of erythromycin twice daily for 14 days, with cure rates as high as 100\%; however, other treatments with topical antibiotics and antifungals have also demonstrated good responses. ${ }^{1-5}$

\section{References}

1. Klatte JL, van der Beek N, Kemperman PM. 100 years of Wood's lamp revised. J Eur Acad Dermatol Venereol 2015; 29:842-7. doi: $10.1111 /$ jdv.12860.

2. Blasco Morente G, Martínez Peinado C, Martínez García E, Tercedor Sánchez J. [Wood's lamp in congenital erythropoietic porphyria]. An Pediatr (Barc) 2014; 81:403-4. doi: 10.1016/j. anpedi.2014.01.005.

3. Wilson BB, Wagenseller A, Noland MM. An atypical presentation of erythrasma. J Am Acad Dermatol 2012; 67:e217-18. doi: 10.1016/j.jaad.2012.04.004.

4. Chodkiewicz HM, Cohen PR. Erythrasma: Successful treatment after single-dose clarithromycin. Int J Dermatol 2013; 52:516-18. doi: 10.1111/j.1365-4632.2011.05005.x.

5. Holdiness MR. Erythrasma and common bacterial skin infections. Am Fam Physician 2003; 67:254. 